ENVIRONMENTAL RESTORATION PROGRAM

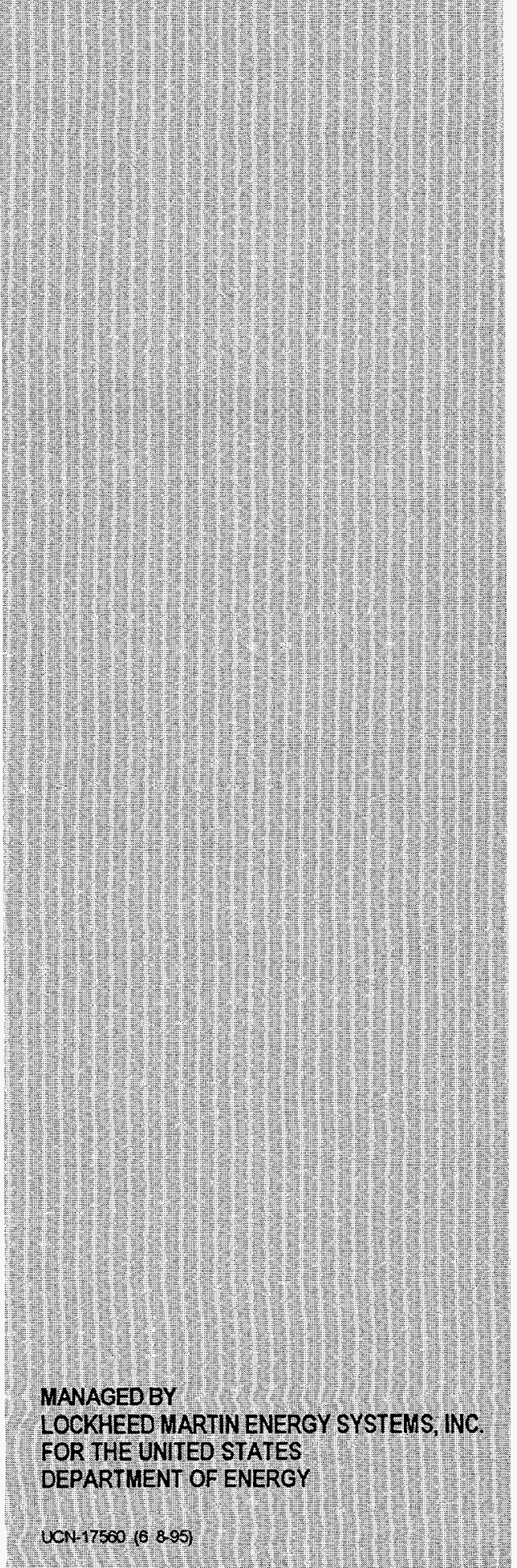

\title{
Inactive Tanks Remediation Program Strategy and Plans for Oak Ridge National Laboratory, Oak Ridge, Tennessee

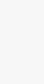

\section{MASTER} RECEVED NOV 191997 OSTI DETREUTION OF THS DOCURENT IS URAMTED ph

This document has been approved by the ORNL Technical Information Office for release to the public. Date: $11 / 6 / 97$ 


\section{STEP, Inc.}

contributed to the preparation of this document and should not be considered an eligible contractor for its review. 


\section{DISCLAMIER}

Portions of this document may be illegible in electronic image products. Images are produced from the best available original document. 


\section{DISCLAIMER}

This repor was prepared as an account of work sponsored by an agency of the United States Government. Neither the United States Government nor any agency thereof, nor any of their employees, makes any warranty, express or implied, or assumes any legal liability or responsibility for the accuracy, completeness, or usefulness of any information, apparatus, product, or process disclosed, or represents that its use would not infringe privately owned rights. Reference herein to any specific commercial product, process, or service by trade name, trademark, manufacturer, or otherwise does not necessarily constitute or imply its endorsement, recommendation, or favoring by the United States Government or any agency thereof. The views and opinions of authors expressed herein do not necessarily state or reflect those of the United States Government or any agency thereof. 
ORNL/ER-297/R2

\title{
Inactive Tanks Remediation Program Strategy and Plans for Oak Ridge National Laboratory, Oak Ridge, Tennessee
}

Date Issued-November 1997

\author{
Prepared by \\ STEP, Inc. \\ Oak Ridge, Tennessee \\ under subcontract 13X-KEP24V \\ Prepared for the \\ U.S. Department of Energy \\ Office of Environmental Management \\ under budget and reporting code EW 20 \\ Environmental Management Activities at \\ OAK RIDGE NATIONAL LABORATORY \\ Oak Ridge, Tennessee 37831 \\ managed by \\ LOCKHEED MARTIN ENERGY SYSTEMS, INC. \\ for the \\ U.S. DEPARTMENT OF ENERGY \\ under contract DE-AC05-84OR21400
}




\section{PREFACE}

This document, Inactive Tanks Remediation Program Strategy and Plans for Oak Ridge National Laboratory, Oak Ridge, Tennessee (ORNL/ER-297/R2), supersedes the previous version (ORNL/ER-297/R1) issued in March 1997. The inactive tank remediation strategy has changed sufficiently such that the March 1997 document does not reflect the current remediation strategy being implemented by the Inactive Tanks Remediation Program. Current efforts focus on remediation of the tank shell and contents. The remediation of piping, ancillary facilities, and contaminated media may be deferred until remediation is initiated for surrounding areas and will be addressed in the watershed Record of Decision projects. The primary changes in the strategy are reflected in the risk screening assessment process, which supports the remedial action decision. Other changes have been made to update the appendix.

This document is consistent with the requirements of the Federal Facility Agreement (FFA) signed by the U.S. Department of Energy, the U.S. Environmental Protection Agency, and the Tennessee Department of Environment and Conservation in November 1991. The FFA was required by the Superfund Amendments and Reauthorization Act portion of the Comprehensive Environmental Response, Compensation, and Liability Act for all federal facilities placed on the National Priorities List. As required by the FFA, this document presents plans and strategies for remediation of the liquid low-level waste tanks that have been removed from service at Oak Ridge National Laboratory in Oak Ridge, Tennessee. This work was performed under Work Breakdown Structure 1.4.12.6.1.01.21 (Activity Data Sheet 3300W)'.

${ }^{1}$ Reference herein to any specific commercial product, process, or service by trade name, trademark, manufacturer, or otherwise, does not necessarily constitute or imply endorsement, recommendation, or favoring by the United States Government or any agency thereof. 


\section{CONTENTS}

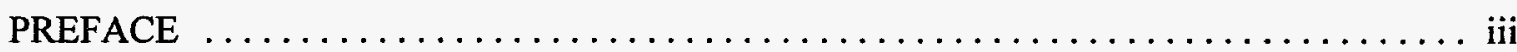

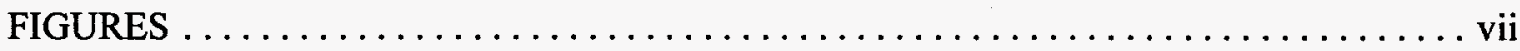

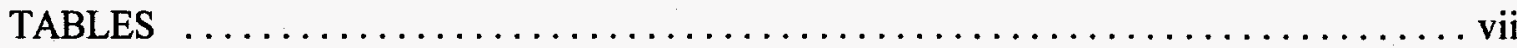

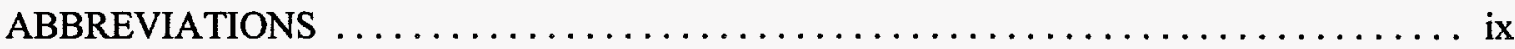

EXECUTIVE SUMMARY $\ldots \ldots \ldots \ldots \ldots \ldots \ldots \ldots \ldots \ldots \ldots \ldots \ldots \ldots \ldots \ldots \ldots \ldots \ldots \ldots$

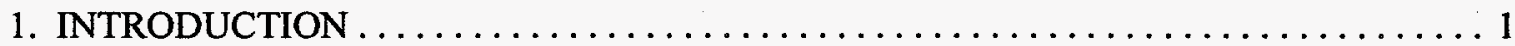

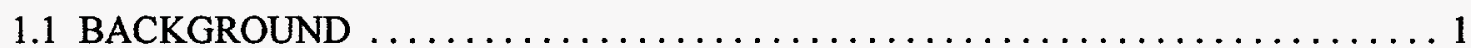

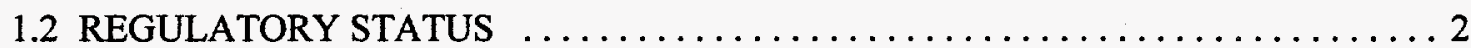

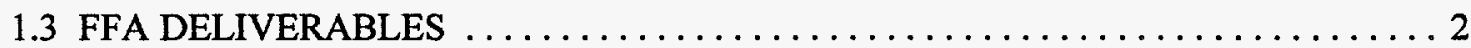

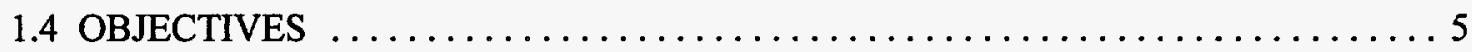

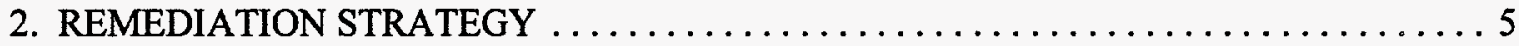

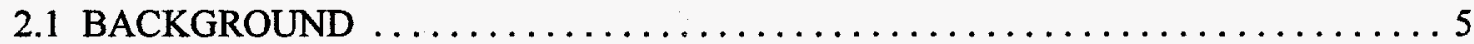

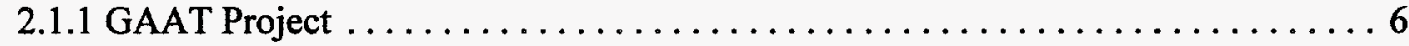

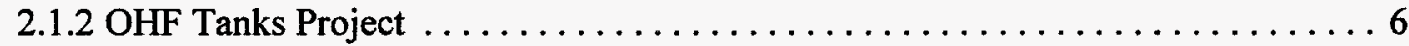

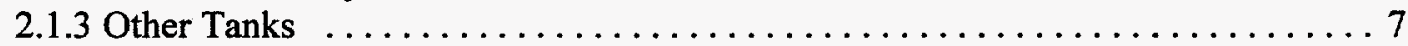

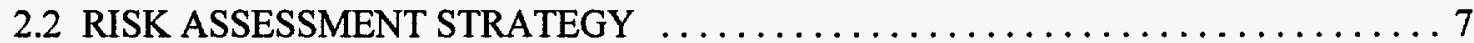

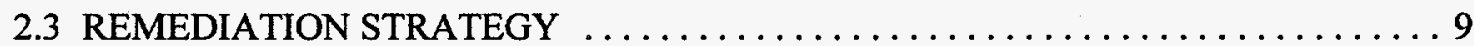

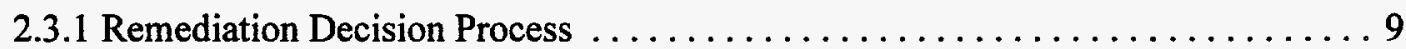

2.3.2 Integration of Environmental Restoration and Waste Management Activities ... 10

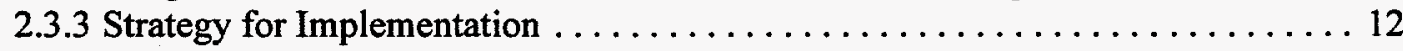

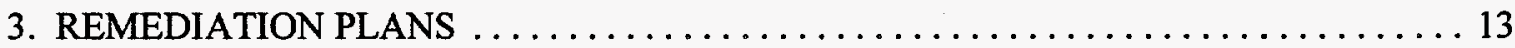

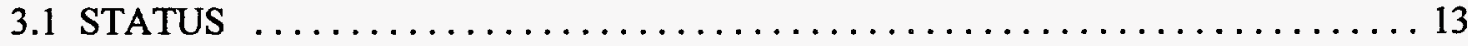

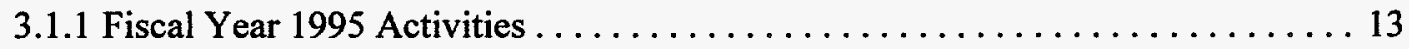

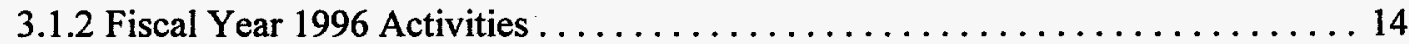

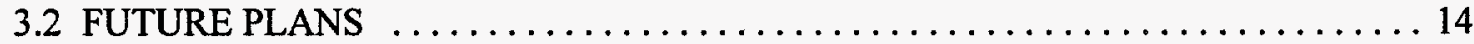

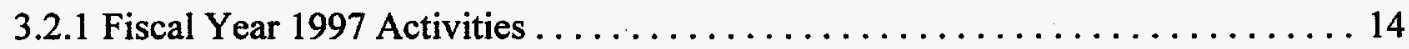

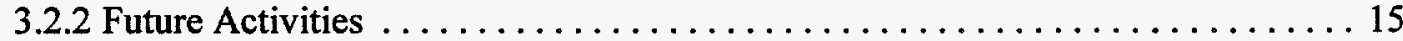

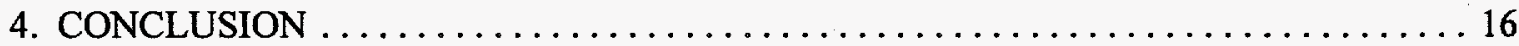

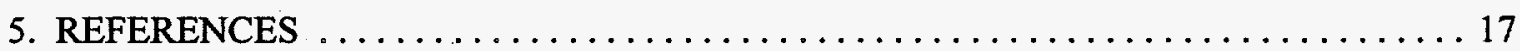

APPENDIX: STATUS OF CATEGORY D LLLW TANK SYSTEMS $\ldots \ldots \ldots \ldots \ldots \ldots$ A-1 


\section{FIGURES}

1 Location map for Bethel Valley LLLW tanks $\ldots \ldots \ldots \ldots \ldots \ldots \ldots \ldots \ldots$

2 Location map for Melton Valley LLLW tanks $\ldots \ldots \ldots \ldots \ldots \ldots \ldots \ldots \ldots \ldots$

3 Site conceptual model for human health risk assessment $\ldots \ldots \ldots \ldots \ldots \ldots \ldots \ldots \ldots$

4 Conceptual LLLW tank remediation decision process $\ldots \ldots \ldots \ldots \ldots \ldots \ldots \ldots \ldots 11$

\section{TABLES}

1 ORNL inactive LLLW tank systems fiscal year 1995 activities $\ldots \ldots \ldots \ldots \ldots \ldots \ldots$

2 ORNL inactive LLLW tank systems fiscal year 1996 activities . . . . . . . . . . . 14

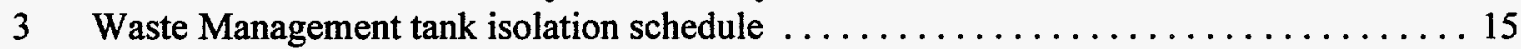

4 Environmental Restoration Inactive Tank Program planned activities . . . . . . . . . 15 


\section{ABBREVIATIONS}

CERCLA Comprehensive Environmental Response, Compensation, and Liability Act

COPC

DOE

DUST

$\mathrm{EE} / \mathrm{CA}$

EPA

ER contaminant of potential concern

U.S. Department of Energy

Disposal Unit Source Term

engineering evaluation/cost analysis

FFA

U.S. Environmental Protection Agency

Environmental Restoration

GAAT

Federal Facility Agreement

LLLW

OHF

Gunite and Associated Tanks

liquid low-level waste

Old Hydrofracture Facility

ORNL

OU

Oak Ridge National Laboratory

operable unit

RCRA

ROD

Resource Conservation and Recovery Act

TDEC

Record of Decision

WAC

Tennessee Department of Environment and Conservation

WAG

waste acceptance criteria

WM

waste area grouping

Waste Management 


\section{EXECUTIVE SUMMARY}

This report presents plans and strategies for remediation of the liquid low-level waste (LLLW) tanks that have been removed from service (also known as inactive tanks) at Oak Ridge National Laboratory (ORNL) in Oak Ridge, Tennessee. These plans and strategies will be carried out by the Environmental Restoration Program's Inactive LLLW Tank Program at ORNL.

The U.S. Department of Energy's (DOE) Oak Ridge Reservation was placed on the National Priorities List on December 21, 1989, and a Federal Facility Agreement (FFA) was signed by DOE, the U.S. Environmental Protection Agency, and the Tennessee Department of Environment and Conservation in November 1991, as required by the Comprehensive Environmental Response, Compensation, and Liability Act (CERCLA). One objective of the FFA is to ensure that LLLW tanks that are removed from service are evaluated and remediated through the CERCLA process. These tanks are defined in Section IX (A)(d) of the FFA as Category D tanks because they are "existing tank systems without secondary containment that are removed from service." These tanks, along with Category $A, B$, and $C$ tanks, are listed in Appendix F of the FFA. This document will focus only on the Category $D$ tanks as defined previously.

Most of the LLLW system at ORNL was installed more than 40 years ago. The original system was singly contained with no cathodic protection or leak detection, and its subsequent modifications were designed to minimize radiation exposure to LLLW system users and operators. New tank systems installed during the past 10 to 15 years incorporated secondary containment and cathodic protection and improved leak-detection features. Thus, the LLLW system is a mix of singly and doubly contained tank system. The portions of the system that have been removed from service consist almost exclusively of tanks without secondary containment. Those tanks known to contain liquid contents that might fluctuate have functioning level-monitoring equipment that are checked regularly.

The approach to remediation of each tank or tank farm must be adapted in response to the specific circumstances of individual tank sites. The approach will be tailored to accommodate feedback on lessons learned from previous tank remediation activities and will not be a rigid step-by-step approach that must be conducted identically for every tank system. However, the approach will follow a multistep decision process.

The overall objective of the Inactive Tank Program is to remediate all LLLW tanks that have been removed from service to the extent practicable in accordance with the FFA requirements. The Inactive Tank Program will focus on the remediation of the tank residues (i.e., contents after tank has been emptied) and tank shell. This strategy is discussed in detail in this report. 


\section{INTRODUCTION}

The strategy for remediation of the liquid low-level waste (LLLW) system tanks located at Oak Ridge National Laboratory (ORNL) that have been removed from service is presented in this report. These tanks are designated Category $\mathrm{D}$ (also known as inactive tanks) in the Federal Facility Agreement (FFA) that was made between the U.S. Department of Energy (DOE), the U.S. Environmental Protection Agency (EPA), and the Tennessee Department of Environment and Conservation (TDEC). This reportalso presents the (1) screening-level risk assessment methodology and other factors considered in the remediation decision process used to support the selected tank remedial action, (2) integration of the Waste Management (WM) Division tank isolation activities and the Environmental Restoration (ER) Program remediation activities, (3) review of past tank remediation activities, and (4) strategy and plans for future tank remediation activities.

\subsection{BACKGROUND}

ORNL is a multidisciplinary research facility that began operation in 1943 as part of the Manhattan Project. The original mission of the laboratory was to develop a prototype graphite reactor and the reactor fuel reprocessing facility. Subsequent to World War II, the primary functions of ORNL were fuel reprocessing research; radioisotopes production and applications development; and nuclear reactor concepts development, testing, and operation. More recently, the laboratory has increased its role in biological, environmental, energy, and materials research. As a consequence of these multidisciplinary research activities, heterogeneous wastes, including solid and liquid radioactive, hazardous, and mixed wastes, have been generated in varying amounts over time. These activities (past and present) have generated LLLW that must be managed and, ultimately, remediated.

The LLLW system is complex, with multiple facilities, users, and operators. The system is used for collection, neutralization, transfer, and concentration of aqueous radioactive waste solutions from generator facilities. Waste solutions are typically accumulated at source buildings, often in collection tanks located inside the buildings, and discharged to below-grade collection tanks that receive wastes from several different source buildings. However, in many instances, LLLW is transferred through unvalved piping directly to underground collection tanks or the central waste collection header from laboratory and hot-cell drains. System upgrades have improved LLLW handling and control. A network of below-grade piping interconnects the various system components.

Most of the LLLW system was installed more than 40 years ago. The original system, installed during the early 1940s, and its subsequent modifications were designed to minimize radiation exposure to LLLW system users and operators. The system includes features such as unvalved, gravity-drained transfer lines to prevent waste backup into generator areas; shielded lines and tanks; and provisions for remote operations to minimize personnel exposure. Design drawings exist for most of these tanks with only a few as-built drawings available. Over the years, tank systems were removed from service as their integrity was breached or as programs were terminated. New tank systems installed during the past 10 to 15 years incorporate secondary containment and cathodic protection and improved leak-detection features. Thus, the LLLW system is a mix of doubly contained tank systems (Category A and B) and singly contained tank systems (Category C and D) as defined in Section IX (A) of the FFA. The tank category, remediation status, and locations in 
Bethel Valley and Melton Valley are shown in Figs. 1 and 2, respectively. These figures also make a distinction between Category D, Group 1 through 5 tanks that are managed by the ER Program and the Category D, Group 6 tanks that are managed by the WM Division, which will be discussed in more detail later in this document.

\subsection{REGULATORY STATUS}

The Superfund Amendments and Reauthorization Act of the Comprehensive Environmental Response, Compensation, and Liability Act (CERCLA) requires an FFA for federal facilities placed on the National Priorities List. The Oak Ridge Reservation was placed on the National Priorities List on December 21, 1989, and the agreement was signed in November 1991 by the DOE Oak Ridge Operations Office, EPA Region IV, and TDEC (DOE 1992). The effective date of the FFA was January $1,1992$.

On the basis of the July 11, 1996, revision to the FFA Appendix F, a total of 57 tanks have been removed from service. These tanks are defined in Section IX (A)(d) of the FFA as Category D tanks because they are "existing tank systems without secondary containment that are removed from service." As such, some of these tank shells have been removed or remediated in place as indicated in Fig. 1 or are currently being evaluated to determine the appropriate remediation strategy as discussed in this document. These tanks and their physical characteristics are listed in the Appendix.

\subsection{FFA DELIVERABLES}

According to the FFA, within 90 days of the date on which a tank is declared inactive DOE must provide EPA and TDEC with a plan and schedule for characterizing tank contents and the risks associated with the tank system. The characterization information is provided in the Waste Characterization Data Manual for the Inactive Liquid Low-Level Waste Tank Systems at Oak Ridge National Laboratory (Bechtel National, Inc. 1993) and the Risk Characterization Data Manual for Category D Inactive Liquid Low-Level Waste Tank Systems at Oak Ridge National Laboratory (Lockheed Martin Energy Systems 1993). These data manuals are controlled documents that are updated as new information becomes available (i.e., as tanks are taken out of service).

On the basis of the results of waste and risk characterization, DOE must then provide EPA and TDEC with a plan and schedule for remediation of inactive tank systems. The initial plan and schedule provided by DOE to meet the FFA requirements is presented in the Remediation Schedule for Inactive Liquid Low-Level Waste Storage Tank Systems at Oak Ridge National Laboratory(H\&R Technical Associates, Inc. 1993). The plan and schedule in this 1993 document have been superseded by changes in remediation. strategy, overall program priorities, and funding. Information presented in Chap. 3 reflects the current schedule for tank shell and content remediation. For tanks or tank groupings that are actively in the CERCLA process, current remediation schedules are negotiated annually and published in Appendix $E$ of the FFA.

Two projects consisting of inactive tanks located at ORNL currently have Appendix E milestones: the Gunite and Associated Tanks (GAAT) remediation project and the Old Hydrofracture Facility (OHF) tanks removal action. Tank remediation activities that have not yet 


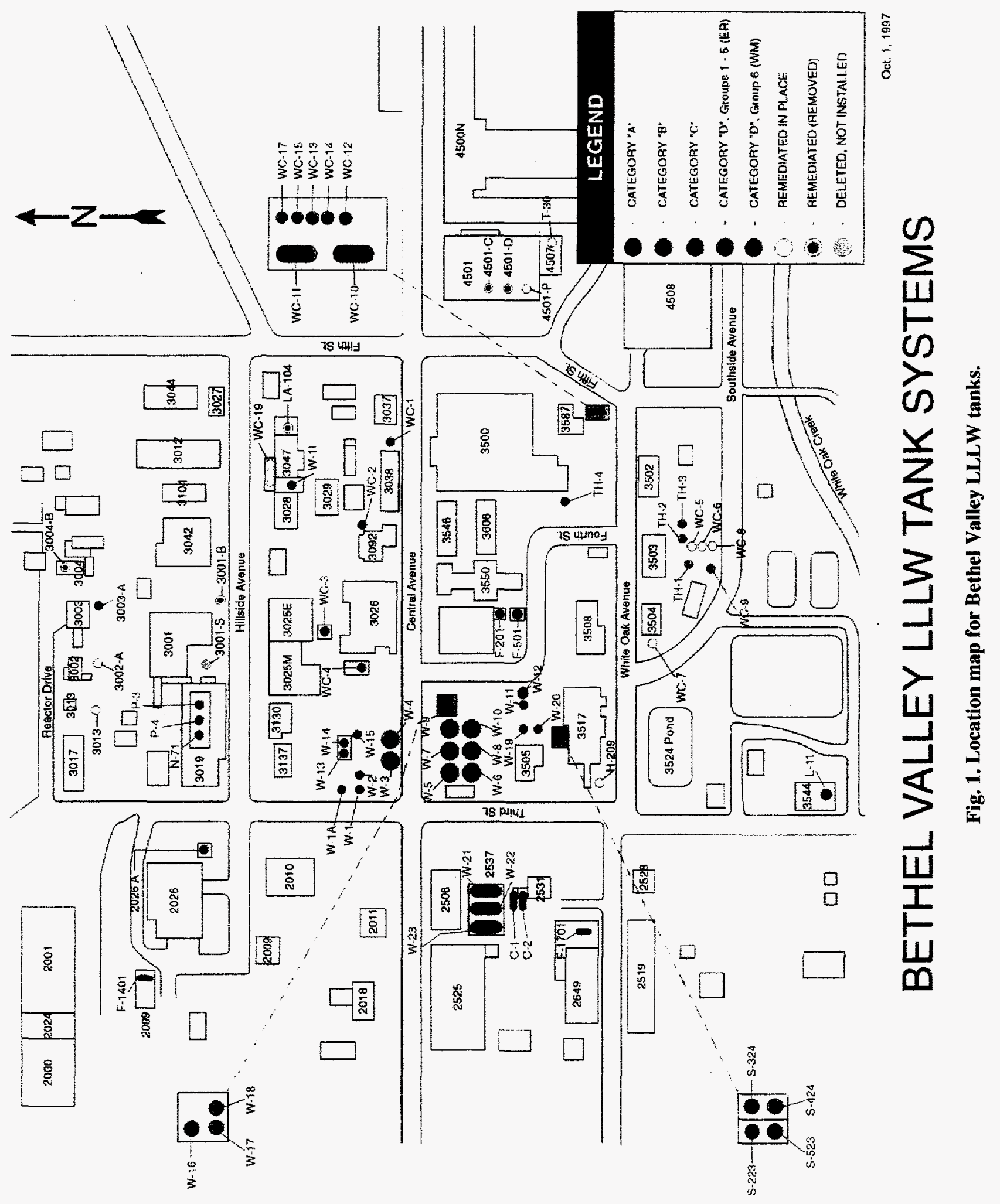




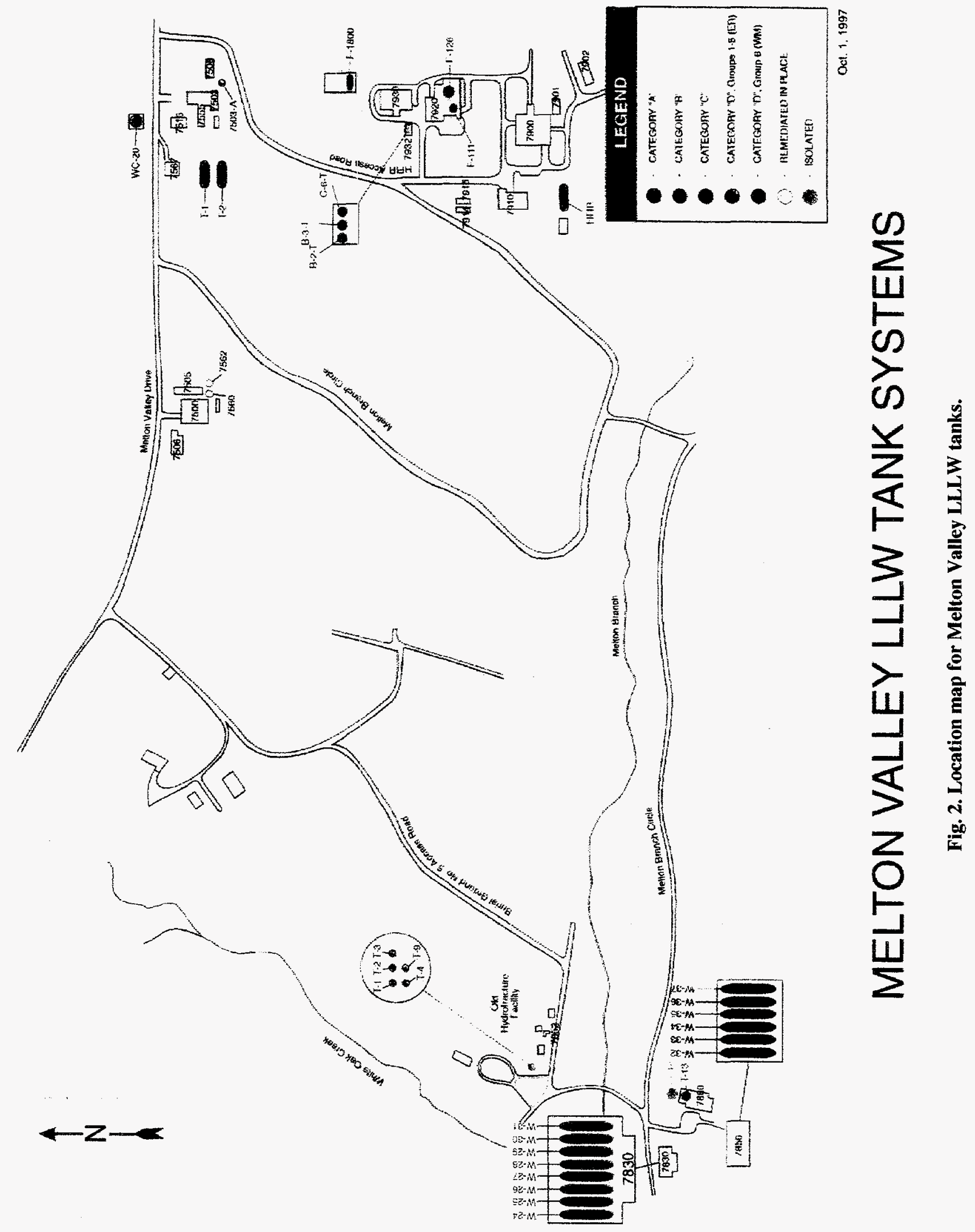


been initiated are prioritized semiannually with remediation activities for the entire ER Program. This prioritization determines when the activity will be funded and, thus, also determines when the activity will begin. The status of the ongoing activities is discussed in Sect. 3.1.

\subsection{OBJECTIVES}

The overall objective of the Inactive Tank Program is to evaluate and remediate all LLLW tanks that have been removed from service to the extent practicable over a reasonable time period in accordance with the FFA requirements. The Inactive Tank Program will focus on the remediation of the tank residues (i.e., contents after tank has been emptied) and tank shell. Contaminated equipment, soil, and/or groundwater associated with the tank system will be considered for remediation on a case-by-case basis. These portions of the tank system may be addressed as part of the tank remediation or be remediated in conjunction with surrounding areas, whichever is the most cost-effective method. The following sections discusses this strategy in detail.

This document will focus on those tanks that are managed by the ER Program (Category D, Group 1-5) as identified in Figs. 1 and 2. However, Sect. 2.3.2 discuss the integration of WM isolation activities associated with the Category D, Group 6 tanks with the ER remediation activities required of these same tanks once they are transferred to the ER Program.

\section{REMEDIATION STRATEGY}

The Inactive Tank Program comprises several projects that work together and in parallel to accomplish remediation of all inactive LLLW tank systems at ORNL. The ER Program's approach for remediating tanks within the inactive LLLW tank systems was first documented in a January 1995 strategy document (H\&R Technical Associates, Inc. 1995). Revision 1 reflects the current Inactive Tank Program strategy for remediation of inactive LLLW tank systems. The following sections will discuss the evolution of this strategy and the current remediation decision process and implementation strategy.

\subsection{BACKGROUND}

The ORNL Category D, Groups 1 through 5 tanks (Figs. 1 and 2) are included in ER Program planning. In 1987, the Resource Conservation and Recovery Act (RCRA) Facility Assessment at ORNL (Oak Ridge National Laboratory 1987) identified tanks as solid waste management units under RCRA. As ORNL developed its remediation strategy, these inactive tanks were included in larger groupings as solid waste management units, within a delineated geographic area, called waste area groupings (WAGs). Investigations and remediation activities would be handled for each WAG as a unit. The tanks were sampled in 1988 to obtain information for use in planning the remediaton of these tanks. When ORNL was placed on the National Priorities List in 1989, the ORNL remediation strategy was adapted for use under CERCLA. The FFA, which became effective in January 1992, identified waste characterization, risk characterization, and remediation requirements, based on CERCLA for the inactive tanks.

The majority of the inactive tanks are contained in WAG 1, which is the main plant area at ORNL. The WAG 1 operable unit (OU) strategy (Bechtel National, Inc. 1992) identified the Gunite 
tanks as an OU, with the highest priority of all the WAG 1 OUs. The remaining WAG 1 inactive tanks were grouped into a lower priority OU because the residual tank contents posed minimal risk. Remaining liquids were removed from the inactive tanks, although some of these tanks receive nonprogrammatic inflows and require periodic pumping. The five OHF tanks were included in the WAG 5 remediation planning, with the remaining tanks included in the WAG for their geographic area.

The GAAT Project and the OHF Tanks Sludge Removal Action are currently in progress and their status is provided in Sects. 2.1.1 and 2.1.2. Some of the low-risk tanks have been remediated as maintenance actions, as discussed in Sect. 2.3. Two watershed-scale Record of Decisions (RODs) will be prepared for ORNL to document the end state after remediation and to define what projects are required to achieve this end state. Any inactive tanks or tank systems that remain to be remediated at the time of the approval of the appropriate ROD (Bethel Valley or Melton Valley area depending on tank location) will be included in this ROD. These watershed RODs are scheduled to be approved by the end of fiscal year 2000. The Inactive Tanks Program will continue to address remediation of the tank shell and resiclual contents as funding permits and coordinate these activities with the watershed ROD projects.

\subsubsection{GAAT Project}

The feasibility study and proposed plan describe the interim remedial action proposed for removing sludges from the GAAT CU. The action proposed in this plan is the removal of sludge from eight tanks (W-3, W-4, W-5, W-6, W-7, W-8, W-9, and W-10). DOE proposes to combine waste from the GAAT OU into the Melton Valley Storage Tanks for interim storage. Seven of the sixteen tanks (W-1, W-1A, W-2, W-11, W-13, W-14, and W-15) referred to as GAAT OU are not addressed as part of this interim action because they contain no sludge, have low contaminant levels, and therefore do not pose a threat in the future to human health and the environment. Tank TH-4 is part of the GAAT OU and contains sludge; however, its contents are very different from the contents of the other sludge-containing tanks. Final decisions regarding remediation of the tank shells, other related equipment, and tank TH-4 sludge will be addressed in future decisions associated with the main ORNL complex (i.e., Bethel Valley ROD).

\subsubsection{OHF Tanks Project}

An engineering evaluation/cost analysis (EE/CA) was prepared in 1996 for the OHF Tanks project. The baseline risk assessment for the OHF tanks was presented in the WAG 5 Remedial Investigation Report (DOE 1995a), which was approved by DOE, EPA, and TDEC in September 1995. The EE/CA developed, evaluated, and recommended a preferred alternative for the non-time-critical removal action to reduce the risk of a release of radioactively contaminated liquid and sludge wastes stored in the OHF tanks. Alternatives considered were in situ treatment, encapsulation, and waste removal from the tanks. After the alternatives were screened, waste removal from the tanks was chosen as the preferred alternative and was achievable without interfering with future actions. On the basis of technology evaluations and screening, a conventional sluicing and pumping operation was selected for removal of tank contents and transfer to the Melton Valley Storage Tanks. Waste removal activities are expected to be implemented in the first part of 1998. The tank shell and associated piping and equipment will be remediated consistent with the White Oak Creek Watershed: Melton Valley Area ROD. 


\subsubsection{Other Tanks}

Other inactive LLLW tanks that are not included in the GAAT or OHF projects must also be remediated as part of the FFA agreement. These tanks are prioritized for remediation based on several factors:

- tank residues/contents and associated risk to the environment,

- tank integrity,

- tank disposal requirements/options (tank contents and shell),

- WM tank isolation schedule,

- remediation activities associated with adjacent facilities/operable units,

- stakeholder (regulators and public) concurrence,

- future land-use considerations, and

- funding availability.

These factors are used in the remediation decision process and are discussed in greater detail in the remainder of this chapter.

\subsection{RISK ASSESSMENT STRATEGY}

The ORNL Inactive Tank Program risk assessment strategy is based on an incremental approach in which quantitative decision rules are used to help ensure a conservative method with a minimum of modeling (DOE 1995b). This conservative, screening-level risk assessment process is used as a decision tool to determine if the tank can be remediated as a maintenance action. The primary radionuclide contaminants of potential concern (COPCs) evaluated include ${ }^{137} \mathrm{Cs}$, ${ }^{60} \mathrm{Co},{ }^{244} \mathrm{Cm},{ }^{239} \mathrm{Pu}$, ${ }^{90} \mathrm{Sr},{ }^{3} \mathrm{H}$ (tritium), ${ }^{241} \mathrm{Am},{ }^{234} \mathrm{U},{ }^{235} \mathrm{U}$, and ${ }^{238} \mathrm{U}$. Inorganic COPCs are also factored into the risk evaluation, but because of their low concentrations, they usually are negligible risk contributors. As stated in many ORNL CERCLA documents, the primary risk drivers are the radionuclides. Ingestion of groundwater is the only exposure pathway that is evaluated for a future residential exposure scenario. Because leached COPCs in groundwater are assumed to be at $100 \%$ concentration in drinking water, this pathway reflects the most conservative risk evaluation as compared with other potential residential exposure pathways (i.e., inhalation or dermal contact). Additional conservative assumptions for the ingestion through the groundwater pathway are a $2 \mathrm{~L} /$ day intake rate for a 350 day/year exposure frequency. Calculated contaminant concentrations in groundwater are used to estimate projected risk by comparison with risk-based screening levels (also referred to as preliminary remediation goals, PRGs).

The site conceptual model for this exposure assessment is presented in Fig. 3. This exposure assessment assumes tank failure (either localized or general) has occurred and contaminants have been released to the surrounding environment. After release from the tank, contaminants are transported to the groundwater interface at the saturated zone by precipitation/infiltration through the unsaturated soil. Precipitation/infiltration into tanks has been modeled by using Oak Ridge Reservation-specific precipitation rates. Infiltration rates are assumed to equal precipitation rates. Vertical fate and transport modeling of contaminant migration into groundwater is performed 


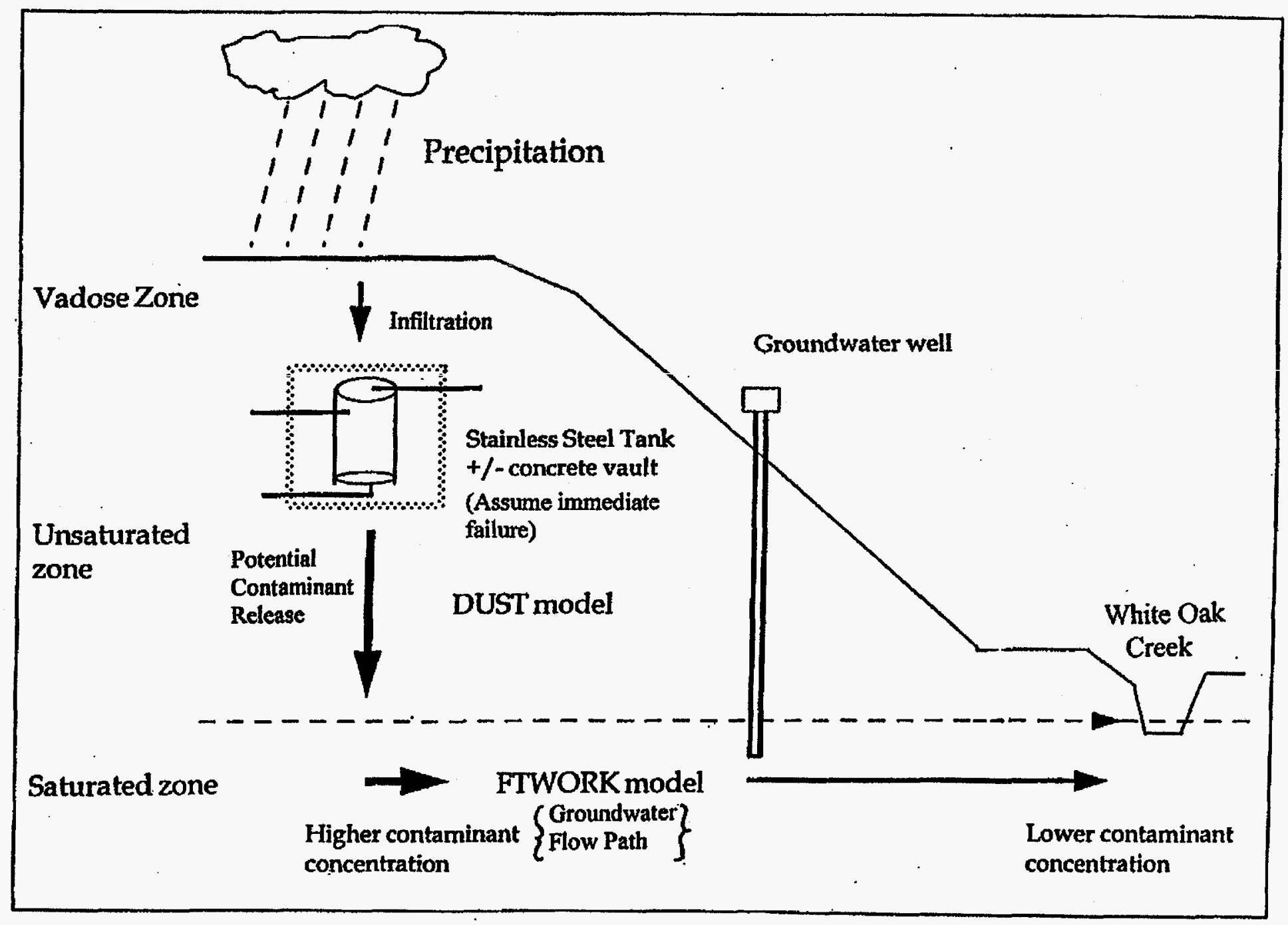

Fig. 3. Site conceptual model for human health risk assessment. 
through the use of the Disposal Unit Source Term (DUST) code developed at the Brookhaven National Laboratory for the Nuclear Regulatory Commission. In the DUST code, one of the assumptions used is that general failure occurs immediately (i.e., time $=0$ ), at which time the container is assumed to no longer provide a barrier for contaminant releases.

Lateral flow through the saturated zone (groundwater medium) is performed by using FTWORK. This is a three-dimensional, finite-difference model that is used to simulate groundwater flow and solute transport process under confined and unconfined conditions. FTWORK was developed for the Savannah River Site to simulate groundwater flow through large, complex, multilayered, fully saturated, porous hydrogeologic systems. The model has been calibrated by ORNL hydrogeologists to simulate groundwater flow underlying the ORNL WAG 1 area (main plant area) and the flow scenario to White Oak Creek.

In summary, this conservative risk assessment model assumes that the tank fails, the tank residual waste leaches into the unsaturated-saturated zone interface, and an on-site resident consumes $2-\mathrm{L} /$ day of the contaminated groundwater. If this risk exceeds the minimal value of EPA's range of concern $\left(10^{-6}\right)$, more realistic assumptions are made (i.e., groundwater modeling is performed to include dilution of contaminants horizontally through the soil column to the nearest surface water source), and the risk is re-evaluated to determine if the tank should be addressed through a more rigorous CERCLA risk assessment/remediation process. These assumptions include (1) attenuation of the contaminants through soil as they transport via groundwater to the nearest stream and (2) the tank is emptied and rinsed, with no more than two inches of liquid and 0.1 inches of sludge remaining on the tank bottom, as applicable with an assumed concentration reduction of two orders of magnitude.

Tanks that pose no significant risks by CERCLA definition still require remediation under the FFA because they are listed in Appendix F of the FFA. If the risk is below the EPA range of concern, the tank shell and residuals are a candidate for remediation as a maintenance action.

\subsection{REMEDIATION STRATEGY}

The overall objective of the Inactive Tank Program is to evaluate and remediate all LLLW tanks that have been removed from service to the extent practicable in accordance with FFA requirements. As stated in Section IX.G.4 of the FFA, "to the extent practicable, the DOE shall remove or decontaminate, or otherwise remediate all residues, contaminated containment system components (liners, etc.), contaminated soils and structures and equipment associated with the tank system(s)." The primary task of the Inactive Tank Program is to remediate the tank residues and tank shell. Other contaminated equipment and soil associated with the tank system will be remediated in conjunction with similar remediation activities for adjacent areas and/or watershed RODs so that consistent and cost-effective remediation of the area can be achieved. The White Oak Creek Watershed: Melton Valley Area and the Bethel Valley RODs, scheduled for approval by the end of fiscal year 2000, will address the remediation of these other components. The following paragraphs will discuss the current remediation strategy for the ORNL inactive LLLW tanks.

\subsubsection{Remediation Decision Process}

In addition to the risk assessment methodology discussed above, other factors are also considered when making remediation decisions. These other factors include the following: 
- tank accessibility (e.g., located in a vault, buried under a building, etc.),

- waste acceptance criteria for disposal facility to receive tank shell,

- contamination adjacent to the site (soil and groundwater),

- future land use in the area,

- future activities associated with adjacent facilities (i.e., decontamination and decommissioning),

- institutional controls, and

- other factors specific for the area.

Figure 4 illustrates conceptually how these factors are evaluated in the remediation decision process. This decision process information is provided to EPA and TDEC before remediation of a particular tank to gain consensus on the remediation decision (e.g., removal versus in-place remediation) before implementation. These factors are expanded on in the following paragraphs.

Tank accessibility includes an evaluation of the size and location of the tank in a vault or soil as well as the diameter of the access riser(s). The size of the tank will determine if this tank can be removed in the future through the use of conventional equipment readily available at ORNL if it is filled today with flowable fill/grout. It was determined that a 40-ton crane (currently available at ORNL) could lift a 4000-gal-capacity tank filled with flowable fill. However, if a 150-ton crane (available in the United States) was used, it could lift a 15,000-gal-capacity tank filled with flowable fill. The location of the tank in a vault or soil will help determine the difficulty and cost effectiveness of accessing the tank for removal.

If a tank is determined to be accessible, then the waste acceptance criteria (WAC) of the disposal facility must be evaluated along with U.S. Department of Transportation requirements for transport of contaminated tank and residues on public highways. If analysis of the tank shell and contents indicates that the WAC and U.S. Department of Transportation requirements cannot be met without expensive, aggressive pretreatment, then the tank should be a prime candidate for in-place stabilization if this is compatible with future plans for the surrounding area.

If a tank is determined to be surrounded by soil or groundwater contamination due to past tank leaks or other sources, the source and associated risks should be evaluated. These situations may require remediation as CERCLA actions. Otherwise, the tank should still be considered a candidate for remediation as a maintenance action.

Consideration of the long-term remediation goals for the overall site will be addressed by the watershed RODs. The Inactive Tank Program will continue to focus on tank shell and content remedial alternatives that are consistent with the ongoing watershed RODs process.

\subsubsection{Integration of Environmental Restoration and Waste Management Activities}

The remediation strategy also considers integration of tank isolation activities planned by the WM Division with ER Program remediation activities. This integration results in cost-effective remediation of LLLW tanks by combining technical forces to make necessary remediation decisions before isolation activities. In 1995, the WM Division began isolating Category D, Group 6 tanks (Figs. 1 and 2) and other tanks taken out of service in recent years. This is accomplished by stopping nonprogrammatic inputs to the tank, emptying the tank, characterizing residual waste liquids and sludge (if any), and isolating the tank from the LLLW system (i.e., cutting and capping critical 


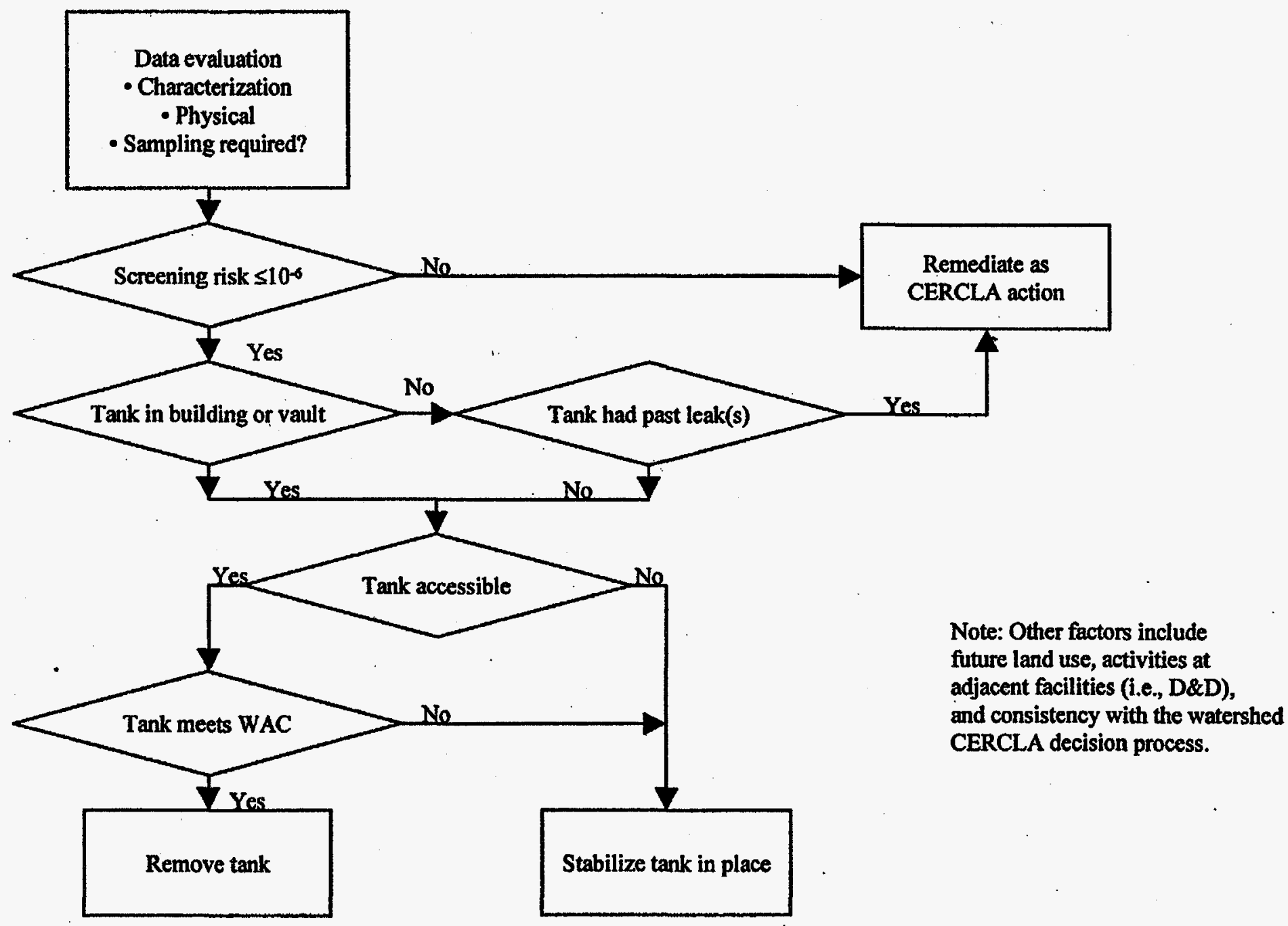

Fig. 4. Conceptual LLLW tank remediation decision process. 
piping). After the tanks are isolated and administratively transferred, it will be the ER Program's responsibility to remediate these tanks.

The integration of ER Program and WM Division activities for these WM tanks eliminates redundant activities and addresses remediation concerns before isolation field activities. This results in cost savings and schedule reduction associated with inactive LLLW tank isolation and remediation. Some of the efficiencies achieved through this integrated effort strategy are as follows.

- The tank is sampled once to gather information needed to make both isolation and remediation decisions by following existing waste management standard operating procedures. Separate ER documents, such as a sampling analysis plan, safety and health plan, and quality assurance project plan, are unnecessary.

- The decision to remove or stabilize the tank in place is made on the basis of a screening-level risk assessment, cost effectiveness, future activities in the vicinity of the tank site, etc., before mobilizing the WM subcontractor, who will carry out the isolation and remedial activities. Thus, only one set of implementation plans (e.g., site safety and health plan, engineering specifications) is prepared to support field activities, and subcontractor personnel are mobilized only once.

- For those tanks where in-place stabilization is the preferred alternative, isolation can be achieved by filling the tank with flowable fill/grout; thus, the costs of excavating soil to expose pipelines and disposing of the potentially contaminated soil as well as the costs of actually cutting and capping lines will not be incurred because placement of the grout serves as a tank and pipeline isolation technique.

There are two primary challenges when integrating these activities: (1) the WM Division's isolation schedule and funding is accelerated compared with the ER Program's project funding profile and prioritization, which is based primarily on risk, and (2) regulator concurrences are contingent upon larger ER programmatic issues and watershed remediation objectives, which directly impact the individual tank project-specific decision process. However, by the end of fiscal year 1998 the funding for both ER and WM activities will be integrated/combined to facilitate the integration of these two programs so that transfer of facilities/responsibilities will not be necessary and funding/scheduling issues will no longer be a hindrance.

\subsubsection{Strategy for Implementation}

In summary, the revised strategy for remediating tanks can and should be viewed as a dynamic, flexible, customized process that must be adapted in response to the specific circumstances of individual tank systems and site conditions. Thus, the implementation strategy will be tailored to accommodate feedback from lessons learned from previous maintenance/remediation activities and will not require a rigid step-by-step implementation process that must be identical for every tank system. The Inactive Tank Program will continue to integrate activities with WM when possible, continue to support the larger tank projects (GAAT and OHF), participate in the watershed RODs to provide consistency, and strive to find new and innovative approaches to tank remediation. Chapter 3 presents the remediation plan for implementing this strategy. 


\section{REMEDIATION PLANS}

\subsection{STATUS}

The current status of ORNL's Category D tanks and summary information on these tanks is provided in the Appendix. Activities completed in fiscal years 1995 and 1996 are described in the following subsections.

\subsubsection{Fiscal Year 1995 Activities}

At the Regulatory Working Group meeting held on February 7, 1995, the remediation strategy, issues, preliminary risk assessment results, and site conceptual model were presented for tanks 3001-B, 3004-B, 3013, and T-30. The consensus among DOE, EPA, and TDEC participants at this meeting was that based on the existing characterization information, because the risk associated with these tanks was below the EPA range of concern and required minimal remedial design, the remediation activities would be addressed as maintenance actions.

Implementation of these maintenance actions involved the efforts of a team that included individuals from the ER Program at ORNL, WM Division (Remedial Action Division and Liquid and Solid Waste Operations), Central Engineering Services, Risk Analysis Section, Chemical Technology Division, and Solid Waste Operations as well as subcontractors. The technical objectives of these maintenance actions were (1) to isolate the inactive tanks from their associated piping systems; (2) to remediate tanks 3001-B, 3004-B, 3013, and T-30; and (3) to obtain knowledge and experience that could be applied to future, more complicated tank removal actions. The activities completed in fiscal year 1995 are summarized in Table 1.

Table 1. ORNL inactive LLLW tank systems fiscal year 1995 activities

\begin{tabular}{|c|c|}
\hline Tank & Maintenance/remediation activities \\
\hline 3001-B & $\begin{array}{l}\text { - Isolated tank from piping. } \\
\text { - } \quad \text { Removed tank from vault. } \\
\text { demined waste discharge line from } 3001 \text { canal } \\
\text { - Filled vault with grout. }\end{array}$ \\
\hline 3004-B & $\begin{array}{l}\text { - } \quad \text { Cut and capped piping connected to tank. } \\
\text { - } \quad \text { Removed tank from vault. } \\
\text { - }\end{array}$ \\
\hline 3013 & $\begin{array}{l}\text { - Cut and capped piping connected to tank. } \\
\text { - Filled tank with grout. }\end{array}$ \\
\hline $\mathrm{T}-30$ & $\begin{array}{l}\text { - Isolated tank from LLLW system by cutting and capping } \\
\text { piping connected to tank. }\end{array}$ \\
\hline
\end{tabular}

Note: These activities are described in detail in the completion report for these tanks (H\&R Technical Associates, Inc., 1996). 


\subsubsection{Fiscal Year 1996 Activities}

In fiscal year 1996, the WM Division and ER Program continued to integrate isolation and remediation activities to address three other tanks (LA-104, WC-7, and 4501-P) as maintenance actions. Other ER Program activities included rinsing tank 7562 and isolating its pipelines and in-place stabilization of tanks H-209 and T-30. The activities completed in fiscal year 1996 are summarized in Table 2.

Table 2. ORNL inactive LLLW tank systems fiscal year 1996 activities

\begin{tabular}{|c|c|}
\hline Tank & Maintenance/remediation activities \\
\hline LA-104 & $\begin{array}{l}\text { - } \quad \text { Cut and capped piping connected to tank. } \\
\text { - Removed tank from vault. }\end{array}$ \\
\hline WC-7 & $\begin{array}{l}\text { - Cut and capped critical piping connected to tank. } \\
\text { - Filled tank with grout. }\end{array}$ \\
\hline 4501-P & $\begin{array}{l}\text { Cut and capped critical piping connected to tank. } \\
\text { Filled tank with grout. }\end{array}$ \\
\hline $\mathrm{T}-30$ & $\begin{array}{l}\text { - Removed lead bricks from vault. } \\
\text { - } \quad \text { Rilled tank and vault with grout. } \\
\text { miscellaneous equipment, and minimal contaminated } \\
\text { surface soil. } \\
\text { - Placed concrete cap over tank vault and reseeded area. }\end{array}$ \\
\hline $\mathrm{H}-209$ & $\begin{array}{l}\text { Disconnected out-of-service instrumentation and piping. } \\
\text { Installed blind flanges in critical piping connected to } \\
\text { tank. } \\
\text { - Filled tank and access riser with grout. }\end{array}$ \\
\hline 7562 & $\begin{array}{l}\text { - } \quad \text { Removed liquid contents. } \\
\text { - } \quad \text { Rinsed tank. } \\
\text { - }\end{array}$ \\
\hline
\end{tabular}

\subsection{FUTURE PLANS}

\subsubsection{Fiscal Year 1997 Activities}

Funding was limited in fiscal year 1997 to address other inactive tank activities. The available funds were used to support limited document preparation (e.g., update of strategy document, fiscal year 1998 implementation plan, prepare tank completion reports), perform limited tank characterization to support maintenance action decisions, and prepare letters to regulators to document remedial action decisions. However, the WM Division currently had funding to isolate eight tanks in fiscal year 1997 and additional tank isolations in the out years as shown in Table 3. As funding is made available, the ER Program will remediate these tanks concurrent with WM Division isolation activities. With additional funds provided, the ER Program remediated tank 7562 and isolated and remediated tank 7560 . In cases where in-place stabilization by filling the tank with flowable fill is applicable, the WM Division may choose to use this as an isolation technique and also achieve tank remediation. 
Table 3. Waste Management tank isolation schedule

\begin{tabular}{|c|c|}
\hline Year & Tank numbers \\
\hline 1997 & WC-5, WC-6, WC-8, WC-19, 3002-A, T-14 \\
\hline 1998 & 2026A, W-12, F201, High Flux Isotope Reactor (97), W1-I, WC-2, WC-14, WC-4 \\
\hline 1999 & W-16 (98), W-17, W-18, WC-10 (98), WC-11, WC-12, WC-13 \\
\hline 2000 & S-223 (99), S-324 (99), S-523 (99), WC-3 (99), WC-9 (99), S-424, F501 (98) \\
\hline 2001 & T-1 (97), T-2 (97), WC-20 (97) \\
\hline \multicolumn{2}{|c|}{$\begin{array}{l}\text { Notes: } \\
\text { 1. (XX) indicates the year that the Category B or C tank will be removed from service as discussed in } \\
\text { the fiscal year 1996/1997 implementation plan (DOE 1996). } \\
2 \text {. This table was derived from a presentation by R. C. Stewart on September } 26,1996 \text { titled } \\
\text { Isolation/Remediation of Waste Management FFA Tanks. The schedule is updated yearly as reported in } \\
\text { the Implementation Plan for LLLW Tank System document [fiscal year } 1998 \text { updated is scheduled for D0 } \\
\text { delivery to DOE in April } 1997 \text { (DOE/OR/01-1587\&D0)]. }\end{array}$} \\
\hline
\end{tabular}

\subsubsection{Future Activities}

The tanks currently maintained by the ER Program will continue to be remediated based on funding and priority. The DOE Environmental Management Ten-Year Plan issued in March 1997 has identified nine ORNL main plant area inactive LLLW tanks for remediation by implementation of the management and integration concept. A project (ORNL Main Plant Inactive Tanks) has been included in the Ten-Year Plan for remediation of problematic tanks in the main plant area. This project assumes that the final remediation decisions for these tanks are included in the Bethel Valley Watershed ROD. The final remediation decision for the Homogeneous Reactor Experiment/Molten Salt Reactor Experiment tanks will be documented in the White Oak Creek Watershed: Melton Valley Area ROD. However, if funding is available, the Inactive Tank Program may remediate some of these Bethel Valley and Melton Valley area tanks as maintenance actions or CERCLA removal actions in advance of the Ten-Year Plan projects. The activities associated with these tanks are listed in Table 4.

Table 4. Environmental Restoration Inactive Tank Program planned activities

\begin{tabular}{ccl}
\hline Tank number & \multicolumn{1}{c}{ Planned activities } \\
\hline WC-1 & - & $\begin{array}{l}\text { Identify and implement tank remediation through the CERCLA removal } \\
\text { action process (i.e., EE/CA). }\end{array}$ \\
W-19 & - & $\begin{array}{l}\text { Identify and implement tank remediation as a maintenance or } \\
\text { removal action. }\end{array}$ \\
W-20 & - & $\begin{array}{l}\text { Identify and implement tank remediation as a maintenance or } \\
\text { removal action. }\end{array}$ \\
Thorium Tank Farm: & - & $\begin{array}{l}\text { Identify and implement tank remediation as a maintenance action. } \\
\text { TH-1, TH-2, TH-3 }\end{array}$ \\
$3003-A$ & - & $\begin{array}{l}\text { Cut and capped critical piping connected to tank. } \\
\text { Remediate as a maintenance action or removal action. }\end{array}$ \\
WC-15 & - $\quad \begin{array}{l}\text { Identify and implement tank remediation through the CERCLA removal } \\
\text { action process as part of the WC-10 tank farm. }\end{array}$
\end{tabular}


Table 4 (continued)

\begin{tabular}{cll}
\hline Tank number & \multicolumn{1}{c}{ Planned activities } \\
\hline WC-17 & - & $\begin{array}{l}\text { Identify and implement tank remediation through the CERCLA removal } \\
\text { action process as part of the WC-10 tank farm. }\end{array}$ \\
$\begin{array}{c}\text { Melton Valley Tank } \\
7503-A\end{array}$ & $\begin{array}{l}\text { Identify and implement tank remediation through the White Oak Creek } \\
\text { Watershed (Melton Valley Area) ROD process. }\end{array}$ \\
\hline
\end{tabular}

In addition to these tanks, the Inactive Tank Program will continue to address remediation concerns for the tanks that are scheduled to be isolated by the WM Division in the future (Table 3 ). This will be accomplished in the near term (i.e., before issuing the Bethel Valley ROD) by integrating isolation and remediation activities for the low-risk, nonproblematic tanks when funding is available. The remaining tank remediation decisions will be more difficult because of uncertainties associated with inflows, contaminants present in the sludge (e.g., transuranics, mixed waste, and, potentially, PCBs), and lack of readily available sludge removal equipment (i.e., commercially available equipment requires some redesign/modification). For those WM tanks that have not been taken out of service (i.e., Category $\mathrm{C}$ tanks) or have not been remediated by the time the Bethel Valley ROD is issued, tank remediation will be addressed in this document.

\section{CONCLUSION}

The challenge for the ER Program is continuing to remediate those tanks that are already a part of the Inactive Tank Program (Table 4) and continuing to work with the Waste Management Remedial Actions Division to integrate isolation and remediation activities with limited funding. Funding limitations are primarily caused by the funding allocation process that focuses on those sites that have the greater risk drivers (i.e., greater potential for the release of contaminants and their residual contents from the site to an off-site receptor), such as the GAAT and OHF sites. The other inactive tank sites usually rank low on a priority system that is based on risk because they have a stainless-steel tank shell, which provides a barrier to the release of contaminants. Most of the releases associated with these tanks are primarily caused by leaking pipelines that have low volumes of contaminated material in them compared with the tank contents. These leaking pipelines were identified as an OU based on findings presented in the WAG 1 OU strategy (DOE 1992) and will be addressed as part of the Bethel Valley ROD scheduled for approval by the end of fiscal year 2000.

Given these considerations and challenges, the ER Inactive Tank Program must still move forward and it will. This can be accornplished by (1) continuing to work with the regulators to gain their consensus on the ER Program remediation strategy presented in this document; (2) continuing to integrate WM Division isolation activities with ER Program remediation activities when possible to remove duplication of effort and cost; and (3) evaluating and implementing a strategy for addressing other ER Program inactive tanks that do not have a risk driver such that appropriate, documented actions can be defined.

It should be recognized that the 'Ten-Year Plan has established a path for addressing these ER Program tanks as projects as part of the watershed RODs. However, the strategy presented in this document has attempted to present opportunities to accelerate the schedule for remediation of the tank shell and contents before finalizing these RODs if funding is available. On the basis of past 
experience, the integration of ER Program remediation activities with WM Division isolation activities has resulted in an estimated $50 \%$ reduction in cost and an accelerated schedule as a result of the integrated isolation/remediation decision-making process, focused sampling effort, elimination of redundant documentation, and single mobilization of trained subcontractor.

\section{REFERENCES}

Bechtel National, Inc., 1992. Operable Unit Strategy Document for Waste Area Grouping 1 at Oak Ridge National Laboratory, Oak Ridge, Tennessee, ORNL/ER-133.

Bechtel National, Inc., 1993. Waste Characterization Data Manual for the Inactive Liquid Low-Level Waste Tank Systems at Oak Ridge National Laboratory, Oak Ridge, Tennessee, DOE/OR/01-1159\&D1.

DOE (U.S. Department of Energy), 1992. Federal Facility Agreement for the Oak Ridge Reservation, DOE/OR-1014. Oak Ridge, Tennessee.

DOE (U.S. Department of Energy), 1995a. Remedial Investigation Report on WAG 5 at Oak Ridge National Laboratory, Oak Ridge, Tennessee, DOE/OR/01-1326\&D2.

DOE (U.S. Department of Energy) Environmental Restoration Office of Program Integration (EM-43), 1995b. Technology Information Exchange Quarterly, Vol. 4, No. 3, "Screening Strategy for ORNL Inactive Tanks Remediation Program," Germantown, Md.

DOE (U.S. Department of Energy), 1996. White Oak Creek Watershed: Melton Valley Area Remedial Investigation Report on WAG 5 at Oak Ridge National Laboratory, Oak Ridge, Tennessee, DOE/OR/01-1546/V1\&D1.

H\&R Technical Associates, Inc., 1993. Remediation Schedule for Inactive Liquid Low-Level Waste Storage Tank Systems at Oak Ridge National Laboratory, Oak Ridge, Tennessee, DOE/OR/01-1138\&D1.

H\&R Technical Associates, Inc., 1995. Inactive Tanks Remediation Program Strategy and Plans for Oak Ridge National Laboratory, Oak Ridge, Tennessee, ORNL/ER-297.

H\&R Technical Associates, Inc., 1996. Completion Report for the Inactive Liquid-Low Level Waste Tank Remediation Project at Oak Ridge National Laboratory, Oak Ridge, Tennessee, ORNL/ER-343.

Lockheed Martin Energy Systems, Inc., Risk Analysis Section, 1993. Risk Characterization Data Manual for Category D Inactive Liquid Low-Level Waste Tank Systems at Oak Ridge National Laboratory, Oak Ridge, Tennessee, DOE/OR/01-1168\&D1.

Oak Ridge National Laboratory, 1987. RCRA Facilities Assessment (RFA) - Oak Ridge National Laboratory, ORNL/RAP-12/V1\&2. Oak Ridge, Tennessee.

STEP, Inc., 1997. Inactive Tanks Remediation Program Strategy and Plans for Oak Ridge National Laboratory, Oak Ridge, Tennessee, ORNL/ER-297/R1. 


\section{APPENDIX}

\section{STATUS OF CATEGORY D LLLW TANK SYSTEMS}


Table A.1. Status of Category D LLLW tank systems

\begin{tabular}{|c|c|c|c|c|c|c|c|}
\hline \multirow{2}{*}{$\begin{array}{c}\text { Tank } \\
\text { Number }\end{array}$} & \multirow{2}{*}{$\begin{array}{c}\text { Tank Construction } \\
\text { Material }\end{array}$} & \multirow{2}{*}{$\begin{array}{l}\text { Capacity } \\
\text { (gal) }\end{array}$} & \multirow{2}{*}{$\begin{array}{c}\text { Current } \\
\text { Content } \\
\text { Volume (gal) }\end{array}$} & \multicolumn{2}{|c|}{ Curie Content } & \multirow{2}{*}{$\begin{array}{l}\text { Inleakage/ } \\
\text { Outleakage }\end{array}$} & \multirow{2}{*}{ Status } \\
\hline & & & & Alpha & Beta & & \\
\hline 2026A & Stainless steel & 500 & $\begin{array}{c}\text { Empty } \\
\text { March } 1996\end{array}$ & TBD & TBD & No & $\begin{array}{l}\text { Remediation } \\
\text { FY } 1998\end{array}$ \\
\hline $3001-B$ & - & - & - & - & - & - & Removed FY 1995 \\
\hline $3001-S$ & - & - & - & - & 一 & - & Nonexistent \\
\hline $3002-\mathrm{A}$ & Stainless steel & 1,600 & Vạries & Varies & Varies & $\begin{array}{l}\text { Nonprogramatic waste } \\
\text { input (filter house) }\end{array}$ & $\begin{array}{l}\text { Remediation } \\
\text { FY } 1997\end{array}$ \\
\hline 3003-A & Concrete & 16,000 & 4,000 (est.) & Negligible & 0.25 & Unknown & Tank evaluation \\
\hline 3004-B & - & - & - & - & - & - & Removed FY 1995 \\
\hline 3013 & Stainless steel & 400 & - & - & - & - & $\begin{array}{l}\text { In place closure } \\
\text { FY } 1995\end{array}$ \\
\hline $4501-\mathrm{C}$ & - & - & - & - & - & - & $\begin{array}{c}\text { Remediated before } \\
\text { FFA }\end{array}$ \\
\hline 4501-D & - & - & - & - & - & - & $\begin{array}{c}\text { Remediated before } \\
\text { FFA }\end{array}$ \\
\hline 4501-P & Stainless steel & 100 & --- & -- & $-\cdots$ & -- & $\begin{array}{l}\text { In place closure } \\
\text { FY } 1996\end{array}$ \\
\hline 7503-A & Stainless steel & 11,000 & Empty & Negligible & Negligible & No evidence of leaks & Tank evaluation \\
\hline 7560 & Stainless steel & 1,000 & Empty & Negligible & Negligible & No evidence of leaks & $\begin{array}{l}\text { Remediation } \\
\text { FY } 1997\end{array}$ \\
\hline
\end{tabular}


Table A.1 (continued)

\begin{tabular}{|c|c|c|c|c|c|c|c|}
\hline \multirow{2}{*}{$\begin{array}{c}\text { Tank } \\
\text { Number }\end{array}$} & \multirow{2}{*}{$\begin{array}{c}\text { Tank Construction } \\
\text { Material }\end{array}$} & \multirow{2}{*}{$\begin{array}{l}\text { Capacity } \\
\text { (gal) }\end{array}$} & \multirow{2}{*}{$\begin{array}{c}\text { Current } \\
\text { Content } \\
\text { Volume (gal) }\end{array}$} & \multicolumn{2}{|c|}{ Curie Content } & \multirow{2}{*}{$\begin{array}{l}\text { Inleakage/ } \\
\text { Outleakage }\end{array}$} & \multirow{2}{*}{ Status } \\
\hline & & & & Alpha & Beta & & \\
\hline 7562 & Stainless steel & 12,000 & $\begin{array}{l}\text { Emptied/Rinsed } \\
\text { September } 1996\end{array}$ & Negligible & 3.0 & No & $\begin{array}{c}\text { Isolated FY } 1996 \\
\text { Remediated } \\
\text { FY } 1997\end{array}$ \\
\hline F-201 & Stainless steel & 40 & $\begin{array}{l}\text { Unknown } \\
\text { volume }\end{array}$ & - & - & No & $\begin{array}{c}\text { Taken Out of } \\
\text { Service in late } \\
\text { FY 1996; Remediate } \\
\text { in FY } 1997\end{array}$ \\
\hline H-209 & Carbon steel & 2,500 (est.) & $\cdots$ & $-\cdots$ & --- & -- & $\begin{array}{l}\text { In place closure } \\
\text { FY } 1996\end{array}$ \\
\hline LA-104 & - & - & - & - & - & - & Removed FY 1996 \\
\hline $\mathrm{S}-424$ & $\begin{array}{c}\text { Stainless steel/glass } \\
\text { lined }\end{array}$ & 500 & Empty & Negligible & Negligible & No & $\begin{array}{l}\text { Remediation } \\
\text { FY } 2000\end{array}$ \\
\hline $\mathrm{T}-1$ & Mild steel & 15,000 & 8,479 & 79.24 & 7292.0 & No & OHF EE/CA \\
\hline $\mathrm{T}-2$ & Mild steel & 15,000 & 10,544 & 46.24 & 3860.0 & No & OHF EE/CA \\
\hline $\mathrm{T}-3$ & $\begin{array}{l}\text { Mild steel/rubber } \\
\text { lined }\end{array}$ & 25,000 & 2,918 & 62.0 & 7859.0 & No & OHF EE/CA \\
\hline $\mathrm{T}-4$ & $\begin{array}{l}\text { Mild steel/rubber } \\
\text { lined }\end{array}$ & 25,000 & 14,668 & 75.05 & 7600.0 & No & OHF EE/CA \\
\hline $\mathrm{T}-9$ & Mild steel & 13,000 & 4,981 & 11.09 & 1245.0 & No & OHF EE/CA \\
\hline
\end{tabular}


Table A.1 (continued)

\begin{tabular}{|c|c|c|c|c|c|c|c|}
\hline \multirow{2}{*}{$\begin{array}{c}\text { Tank } \\
\text { Number }\end{array}$} & \multirow{2}{*}{$\begin{array}{c}\text { Tank Construction } \\
\text { Material }\end{array}$} & \multirow{2}{*}{$\begin{array}{c}\text { Capacity } \\
\text { (gal) }\end{array}$} & \multirow{2}{*}{$\begin{array}{c}\text { Current } \\
\text { Content } \\
\text { Volume (gal) }\end{array}$} & \multicolumn{2}{|c|}{ Curie Content } & \multirow{2}{*}{$\begin{array}{l}\text { Inleakage/ } \\
\text { Outleakage }\end{array}$} & \multirow{2}{*}{ Status } \\
\hline & & & & Alpha & Beta & & \\
\hline $\mathrm{T}-14$ & Concrete & 48,500 & $\begin{array}{l}\text { Unknown; Jan. } \\
97 \text { video shows } \\
\text { sludge and } \\
\text { hardened grout }\end{array}$ & Negligible & Negligible & No & $\begin{array}{l}\text { Remediation } \\
\text { FY } 1998\end{array}$ \\
\hline $\mathrm{T}-30$ & Stainless steel & 825 & $\cdots$ & -- & $\cdots$ & --- & $\begin{array}{c}\text { In place closure } \\
\text { FY } 1996\end{array}$ \\
\hline TH-1 & Stainless steel & 2,500 & Empty & Negligible & Negligible & No evidence of leaks & Tank evaluation \\
\hline TH-2 & Stainless steel & 2,400 & Empty & Negligible & Negligible & No evidence of leaks & Tank evaluation \\
\hline TH-3 & Stainless steel & 3,300 & Empty & Negligible & Negligible & No evidence of leaks & Tank evaluation \\
\hline TH-4 & Gunite & 17,900 & 8,000 & 3.08 & 10.5 & Inleakage & GAAT OU \\
\hline W-1 & Gunite & 4,800 & 3,100 & Negligible & 0.11 & Inleakage & GAAT OU \\
\hline$W-1 A$ & Stainless steel & 4,000 & Varies & Varies & Varies & Inleakage & GAAT OU \\
\hline W-1I & Stainless steel & 500 & Empty & $\begin{array}{l}\text { Probably } \\
\text { high }\end{array}$ & $\begin{array}{l}\text { Probably } \\
\text { high }\end{array}$ & No & $\begin{array}{l}\text { Remediation } \\
\text { FY } 2001\end{array}$ \\
\hline W-2 & Gunite & 4,800 & 2,000 & Negligible & 0.05 & Inleakage & GAAT OU \\
\hline$W-3$ & Gunite & 42,500 & 16,000 & 2.96 & 523.9 & Inleakage & GAAT OU \\
\hline$W-4$ & Gunite & 42,500 & 29,000 & 4.0 & 194.5 & Inleakage & GAAT OU \\
\hline W-5 & Gunite & 170,000 & 29,300 & 1.0 & 144.4 & Inleakage & GAAT OU \\
\hline W-6 & Gunite & 170,000 & 42,000 & 6.32 & 940.0 & Inleakage & GAAT OU \\
\hline
\end{tabular}


Table A.1 (continued)

\begin{tabular}{|c|c|c|c|c|c|c|c|}
\hline \multirow{2}{*}{$\begin{array}{l}\text { Tank } \\
\text { Number }\end{array}$} & \multirow{2}{*}{$\begin{array}{c}\text { Tank Construction } \\
\text { Material }\end{array}$} & \multirow{2}{*}{$\begin{array}{l}\text { Capacity } \\
\text { (gal) }\end{array}$} & \multirow{2}{*}{$\begin{array}{c}\text { Current } \\
\text { Content } \\
\text { Volume (gal) }\end{array}$} & \multicolumn{2}{|c|}{ Curie Content } & \multirow{2}{*}{$\begin{array}{l}\text { Inleakage/ } \\
\text { Outleakage }\end{array}$} & \multirow{2}{*}{ Status } \\
\hline & & & & Alpha & Beta & & \\
\hline W-7 & Gunite & 170,000 & 3,500 & 11.14 & 2800.0 & Probably not & GAAT OU \\
\hline$W-8$ & Gunite & 170,000 & 66,000 & 11.58 & 3410.0 & Inleakage & GAAT OU \\
\hline W-9 & Gunite & 170,000 & 47,000 & 43.08 & 2094.0 & Very slight leakage & GAAT OU \\
\hline $\mathrm{W}-10$ & Gunite & 170,000 & 105,400 & 83.2 & $13,400.0$ & Very slight leakage & GAAT OU \\
\hline$W-11$ & Gunite & 1,500 & 450 & Negligible & Negligible & $\begin{array}{l}\text { Inleakage during heavy } \\
\text { rain }\end{array}$ & GAAT OU \\
\hline $\mathrm{W}-12$ & Stainless steel & 700 & Varies & Varies & Varies & Slight Inleakage & $\begin{array}{l}\text { Remediation } \\
\text { FY } 1998\end{array}$ \\
\hline$W-13$ & Stainless steel & 2,000 & Empty & 0.40 & 65.0 & No evidence of leaks & GAAT OU \\
\hline W-14 & Stainless steel & 2,000 & Empty & 0.22 & 26.0 & No evidence of leaks & GAAT OU \\
\hline $\mathrm{W}-15$ & Stainless steel & 2,000 & Empty & Negligible & Negligible & No & GAAT OU \\
\hline $\mathrm{W}-17$ & Stainless steel & 2,250 & Varies & - & - & Inleakage & $\begin{array}{l}\text { Remediation } \\
\text { FY } 1999\end{array}$ \\
\hline W-18 & Stainless steel & 2,250 & Varies & - & - & Inleakage & $\begin{array}{l}\text { Remediation } \\
\text { FY } 1999\end{array}$ \\
\hline W-19 & Stainless steel & 2,250 & Empty & Negligible & Unknown & Dry when last inspected & $\begin{array}{l}\text { Remediation } \\
\text { FY } 1999\end{array}$ \\
\hline $\mathrm{W}-20$ & Stainless steel & 2,250 & Empty & Negligible & Unknown & Dry when last inspected & $\begin{array}{l}\text { Remediation } \\
\text { FY } 1999\end{array}$ \\
\hline WC-1 & Stainless steel & 2,150 & Empty & Negligible & Negligible & No (since March) & Tank evaluation \\
\hline
\end{tabular}


Table A.1 (continued)

\begin{tabular}{|c|c|c|c|c|c|c|c|}
\hline \multirow{2}{*}{$\begin{array}{c}\text { Tank } \\
\text { Number }\end{array}$} & \multirow{2}{*}{$\begin{array}{c}\text { Tank Construction } \\
\text { Material }\end{array}$} & \multirow{2}{*}{$\begin{array}{l}\text { Capacity } \\
\text { (gal) }\end{array}$} & \multirow{2}{*}{$\begin{array}{c}\text { Current } \\
\text { Content } \\
\text { Volume (gal) }\end{array}$} & \multicolumn{2}{|c|}{ Curie Content } & \multirow{2}{*}{$\begin{array}{l}\text { Inleakage/ } \\
\text { Outleakage }\end{array}$} & \multirow{2}{*}{ Status } \\
\hline & & & & Alpha & Beta & & \\
\hline WC-4 & Stainless steel & 1,700 & Varies & Varies & Varies & Very slight Inleakage & $\begin{array}{l}\text { Remediation } \\
\text { FY } 1998\end{array}$ \\
\hline WC-5 & Stainless steel & 1,000 & Varies & Varies & Varies & $\begin{array}{c}\text { Nonprogramatic waste } \\
\text { input }\end{array}$ & $\begin{array}{l}\text { In place closure } \\
\text { FY } 1997\end{array}$ \\
\hline WC-6 & Stainless steel & 500 & $\begin{array}{c}\text { Varies } \\
.\end{array}$ & Varies & Varies & No & $\begin{array}{c}\text { In place closure } \\
\text { FY } 1997\end{array}$ \\
\hline WC-7 & Stainless steel & 1,100 & Empty & Negligible & Negligible & No & $\begin{array}{c}\text { In place closure } \\
\text { FY } 1996\end{array}$ \\
\hline WC-8 & Stainless steel & 1,000 & Varies & Varies & Varies & $\begin{array}{l}\text { Nonprogramatic waste } \\
\text { input (pump prime } \\
\text { water) }\end{array}$ & $\begin{array}{c}\text { In place closure } \\
\text { FY } 1997\end{array}$ \\
\hline WC-11 & Stainless steel & 4,000 & Varies & Varies & Varies & $\begin{array}{l}\text { Nonprogramatic waste } \\
\text { input (filter pit, cell } \\
\text { ventilation pump) }\end{array}$ & $\begin{array}{l}\text { Remediation } \\
\text { FY } 1999\end{array}$ \\
\hline WC-12 & Stainless steel & 1,000 & Varies & Varies & Varies & $\begin{array}{l}\text { Nonprogramatic waste } \\
\text { input (sump) }\end{array}$ & $\begin{array}{l}\text { Remediation } \\
\text { FY } 1999\end{array}$ \\
\hline WC-13 & Stainless steel & 1,000 & Varies & Varies & Varies & $\begin{array}{l}\text { Nonprogramatic waste } \\
\text { input (floor sump) }\end{array}$ & $\begin{array}{l}\text { Remediation } \\
\text { FY } 1999\end{array}$ \\
\hline WC-14 & Stainless steel & 1,000 & Varies & Varies & Varies & $\begin{array}{c}\text { Nonprogramatic waste } \\
\text { input }\end{array}$ & $\begin{array}{l}\text { Sludge removal in } \\
\text { FY 1997; } \\
\text { Remediation } \\
\text { FY } 1998\end{array}$ \\
\hline
\end{tabular}


Table A.1 (continued)

\begin{tabular}{|c|c|c|c|c|c|c|c|}
\hline \multirow{2}{*}{$\begin{array}{c}\text { Tank } \\
\text { Number }\end{array}$} & Tank Construction & Material & \multirow{2}{*}{$\begin{array}{c}\text { Capacity } \\
\text { (gal) }\end{array}$} & $\begin{array}{c}\text { Current } \\
\text { Content } \\
\text { Volume (gal) }\end{array}$ & Alpha & Beta & \multicolumn{2}{|c|}{$\begin{array}{c}\text { Curie Content } \\
\text { Outleakage }\end{array}$} & Status \\
\cline { 5 - 7 } & SC-15 & Stainless steel & 1,000 & 1,000 & 0.0001 & 0.002 & $\begin{array}{c}\text { No } \\
\text { Remediation } \\
\text { FY 1999 }\end{array}$ \\
\hline WC-17 & Stainless steel & 1,000 & 400 & Negligible & Negligible & Inleaks groundwater & $\begin{array}{c}\text { Remediation } \\
\text { FY 1999 }\end{array}$ \\
\hline WC-19 & Stainless steel & 2,250 & Varies & Varies & Varies & Suspected Inleakage & $\begin{array}{c}\text { Taken Out of } \\
\text { Service in late } \\
\text { FY 1996; } \\
\text { Remediation } \\
\text { FY 1997 }\end{array}$ \\
\hline
\end{tabular}

CERCLA = Comprehensive Environmental Response, Compensation, and Liability Act; GAAT = Gunite and Associated Tanks; EE/CA = engineering evaluation/cost analysis; $\mathrm{OHF}=$ Old Hydrofracture Facility; FY = Fiscal Year; OU = Operable Unit

Source: Adapted from Remediation Schedule for Inactive LLLW Storage Tanks at Oak Ridge National Laboratory, Oak Ridge, Tennessee, DOE/OR/01-1138\&D1, Table A.1. (p. 19). 


\section{DISTRIBUTION}

1. L. V. Asplund

2. C. A. Bednarz

3. W. D. Brickeen

4. W. R. Clark

5. J. T. Etheridge

6-7. D. L. Garrett

8. L. L. Kaiser

9. T. M. Koepp

10. A. J. Kuhaida, Jr.

11. J. A. Mayo

12. P. T. Owen

13. L. B. Raulston

14. S. T. Rudell

15. R. W. Stewart

16. S. D. Van Hoesen

17. M. L. Whitehead

18. Central Research Library

19. File-EMEF DMC-RC

20. A. Brill, STEP, Inc., 1006 Floyd Culler Court, Oak Ridge, Tennessee 37830

21. R. C. Sleeman, Director, Environmental Restoration Division, DOE Oak Ridge Operations Office, P.O. Box 2001, Oak Ridge, TN 37831-8541

22. T. Conant, Advances Sciences, Inc., 800 Oak Ridge Turnpike, Suite C-260, Oak Ridge, TN 37830

23. J. Hawk, Advances Sciences, Inc., 800 Oak Ridge Turnpike, Suite C-260, Oak Ridge, TN 37830 